Technique as Culture in

Postmodernist Borderland Ethnic American Novel:

A Cultural Reading of Technique in

Sandra Cisneros' Caramelo and Diana Abu-Jaber's Crescent.

Dr.Eman Helmy El-Meligi

Associate Professor, Department of English,

Faculty of Arts, Damanhur University 


\section{Abstract \\ Technique as Culture in \\ Postmodernist Borderland Ethnic American Novel: \\ A Cultural Reading of Technique in \\ Sandra Cisneros' Caramelo and Diana Abu-Jaber's Crescent.}

The cultural dimensions of Sandra Cisneros' Caramelo and Diana Abu-

Jaber's Crescent can be perceived through a study of the postmodernist techniques used like metafiction, magic realism, stories-within-the-story, multiple narrators, interlinguality, and paratexts, as thresholds of the text. These techniques mirror and accentuate cultural concepts underlying and shaping both novels such as, amongst others, Jose David Saldivar's “border trope”, Raul Homero Villa's "barrio-logos” and Gloria Anzaldua's “the Nueva Mestiza”. This study perceives both novels as the specific "Borderland" genre defined by Saldivar as merging cultural hybridity, the Chicana feminist, the postmodern, the postcolonial, and the comparative with popular culture, bilinguality and dialogism. If the terms are literal in the case of the Chicana Caramelo, they are metaphorically applied to Crescent, especially with Andalucia and The Arabian Nights looming in both works. The borderland novelistic genre and cultural theory are situated physically or metaphorically at the liminal zone. Furthermore, they are beautifully embodied by both Lala, in Caramelo, and Sirine, in Crescent, the new Shahrazad or the hybrid narrator, through whose exilic consciousness all tales are filtered and then offered in a borderland counternarrative. 


\section{ملخص باللغة العربية}

قراءة نقدية مقارنة للتكنيك كأداة ثقافية فى روايتى بعليه

"كرامللو" لساندرا سيزنيروز و"الهالال" لديانا أبو جابر.

يقدم هذا البحث قراءة مقارنة للتكنيك كأداة ثقافية فى روايتى"كرامللو" لساندرا سيزنيروز و"الهلال" لديانا أبو جابرفى ضوء المصطلحات النقدية لديفيد سالديفار وراؤل فيلا وجلوريا أنزالدوا، حيث يعمل التكنيك الفنى والروائى كأداة ثقافية تكشف الكثير من سمات الأدب الأمريكى من أصل الصال مكسيكى وعربى التى تعتبر راويتها الهجينة رمزا للهوية التى تستمد سماتها المتفردة من انتمائها

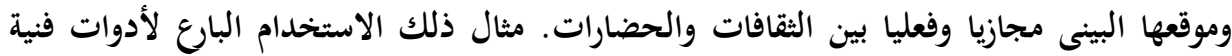

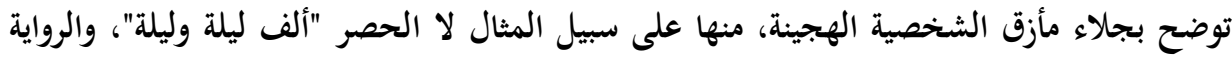

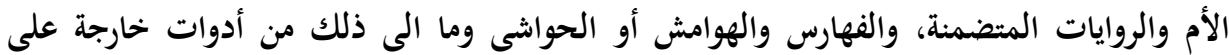

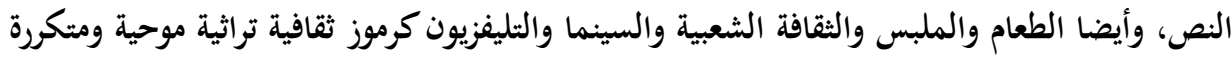

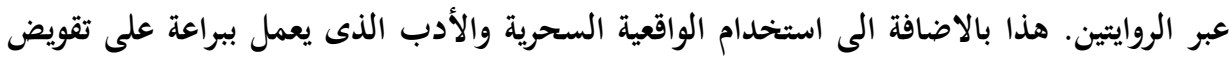

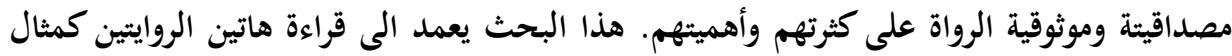

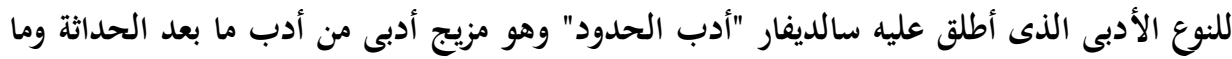

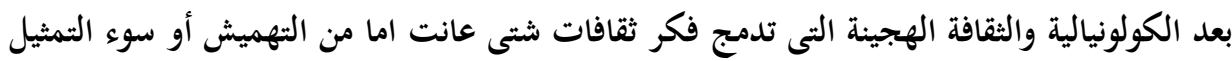
والتى تمنح قوة الحكى والسرد للراوية الهرجينة أو شهرزاد الجديدة التى تتمثل هذه الحضارات وتغربلها أيضا وتمزج ببراعة, ما جرى العرف بتسميته, الثقافة "الرفيعة" بالثقافة "الشعبية". 
The cultural dimensions of Sandra Cisneros' Caramelo and Diana Abu-Jaber's Crescent can be perceived through a study of the postmodernist techniques used like metafiction, magic realism, storieswithin-the-story, multiple narrators, interlinguality, and paratexts, as thresholds of the text. These techniques mirror and accentuate cultural concepts underlying and shaping both novels such as, amongst others, Jose David Saldivar's "border trope", Raul Homero Villa's "barriologos" and, most importantly, Gloria Anzaldua's "the Nueva Mestiza". If the terms are literal in the case of the Chicana Caramelo, they are metaphorically applied to Crescent, especially with Andalucia and The Arabian Nights looming in both works. This research starts with an introduction to the theoretical, cultural and technical aspects first, briefly, as reflected on both novels, then as expounded by their theoreticians. Afterwards, cultural aspects as projected by postmodernist techniques will be analyzed in both novels, all highlighting their "borderland" genre, defined by Saldivar, as merging cultural hybridity, the Chicana feminist, the postmodern, the postcolonial, and the comparative with popular culture, bilinguality and dialogism (BM 23, 29, 35, 14): "US-Mexico border women represent themselves in the shaping of the historical and literary record" (BM 25). Furthermore, these alternative histories, contexts, subjectivities, and spatialities, maintains Saldivar, pave the way for a Chicana cultural theory situated physically or metaphorically at the borderland. Both Lala, in Caramelo, and Sirine, in Crescent, embody this new Shahrazad or the hybrid feminist narrator, through whose consciousness all tales are filtered then offered in a borderland counternarrative, exemplifying Saldivar's notions of "borderland" cultural theory and genre.

\section{Nueva Mestiza, at Barrio-Logos, Telling Her Border Counter- Narrative}

Lala, in Caramelo, and Sirine, in Crescent, act like the Nueva Mestiza or the new hybrid woman offering, through her resistant border trope, her counter-narrative. Furthermore, she brilliantly and intuitively reaches out to her group, inhabiting the same barrio-logos or liminal zone, as well as to the Other. Postmodernist techniques reflect these cultural concepts underlying both ethnic works. Paratexts, or the thresholds of the text, mirror the idea of the periphery or the border trope. Footnotes haunt Caramelo to offer her story instead of the traditional his-tory. Appendices follow the story of Crescent with an intervening 
autobiographical sketch, interviews and food recipes that accentuate the similarity between the author Abu-Jaber and the protagonist Sirine. Similarly disrupting the fictional mode and the suspension of disbelief are the Epigraph and Disclaimer at the outset of Caramelo and the historical Chronology following the told story. The agent linking all these metafictional devices is always the female narrator or Shahrazad, whose main or frame story is infiltrated by several stories-within-thestory, all filtered through her own consciousness. That's how the Nueva Mestiza figures both technically and thematically. The barrio-logos or the liminal zone is metaphorical in California and Texas for Chicanas in Cisneros. Nevertheless, it is coupled with a physical, spatial border experience in the whole annual journey undertaken by Lala and her family to meet their extended family in Mexico and be more informed about both family and national heritage. The moving barrio-logos is reminiscent of the one undertaken by Cisneros herself as an adolescent and in the telenovelas upheld in the novel as a simulacrum. In AbuJaber, besides the metaphorical liminal position of Arab Americans, Sirine's restaurant, gathering both minorities and Americans, is literally emblematic of the barrio-logos, more positively than negatively. Han's Middle Eastern border experiences tend to be more horrific, however, than positive.

Several undercurrents are common in Sandra Cisneros' Caramelo and Diana Abu-Jaber's Crescent. Among these are the double exilic consciousness, hybridity, border crossing, food and the rebozo knitting as 'objective correlatives' and gendered symbols. On the other hand, in both works, loom stereotypes inherent in the depiction of Ethnic Americans, the journey motif, pop culture, as well as the media and soap operas as subtexts glimmering beneath the Arab American and Chicana historia. Equally significant is the story-telling technique, blending the story-within-the-story with the frame story, as a unifying counternarrative voicing minority discourse in both Abu-Jaber and Cisneros. Furthermore, also similar is what Genette terms, paratextuality, evident in epigraphs, prologues and footnotes, in the case of Cisneros, and in indices, including an interview, an autobiographical sketch, recipes for Arab dishes, and questions addressed to the reader, in the case of AbuJaber (Paratexts 284, 235, 359, 114, 22, 144). If The Arabian Nights works as the intellectual and narrative framework and the voice qualifying minority discourse, Um-Nadia's café in Crescent and the journey and the saga genre in Caramelo work as the "barrio-logos" of 
the "nueva mestiza". Although Crescent is not a saga proper, the generational, genealogical strain is clearly evident in the ethnic American stories of the restaurant dwellers and specifically in Han's poignant life-history.

Although the journey does not provide the main structural backbone of Abu-Jaber's narrative, like Cisneros', the journey and the quest motifs obviously inform Han's life and eventual decision to go back to his roots in Iraq. Mexican discourse and narrative are embodied in Victor in Crescent, together with the constant harking back to Andalucía, the epitome of the historic hybrid harmony of Arab and Spanish culture. Similarly, through The Arabian Nights, Arab culture works as the technique and discourse informing Cisneros' novel. Another common impact on both novels is that of Brown Skin, White Masks, as regards motifs like the 'native informer', 'internalizing' colonial 'dependency' and 'inferiority complex', as postulated earlier by Frantz Fanon. These complexes prove to have contaminated the individuation and psychological health of some Chicanos and Arab Americans.

\section{Border Trope and Borderland Genre and Theory}

In his Border Matters: Remapping American Cultural Studies, Jose David Saldivar explains that "borderlands cultural theory" remaps American cultural studies, merging cultural hybridity, the Chicana feminist, the postmodern, the postcolonial, and the comparative with popular culture, bilinguality and dialogism (BM 23, 29, 35, 14). "USMexico border women represent themselves in the shaping of the historical and literary record" (BM 25). These alternative histories, contexts, subjectivities, and spatialities pave the way for a Chicana cultural theory situated physically and metaphorically at the borderland. "Culture is by nature heterogeneous and necessarily works through a realm of borders" (BM 9). One of the relevant terms defined by Saldivar is "transfrontera contact zone" that refers both to US-Mexico border and to other "geopolitical zones"; the transfrontera is a liminal and "social space of subaltern encounters" and hybrid cultures, where new identities and relations are negotiated and manufactured (BM 13), and lives cross over, traverse and mix. US-Mexico border writing produces a "theory of culture", where liminal avenues depict the mestizo/a or hybrid culture and interrogate uneven power relations (BM 14). It is a "continuous encounter between two or more reference codes and tropes" in a site of 
cultural struggle and resistance, hence interlinguality and switching of codes. Saldivar explains his choice of the liminal geopolitical space or the transfrontera contact zones, embodying the writer's strategies of representation: "The US-Mexico border changes pesos into dollars, humans into undocumented workers, choloslas (Chicano youth culture) into punks, people between cultures into people without culture" ( $B M$ 8).

Exemplified by Mexican telenovelas and corridos, in which border writing and theory abound, pop culture and oral narratives redraw the boundaries between "folkore and the counterdiscourses of marginality" ( $B M$ 17). The borderland migrant cultures shuffle the mainstream "US Bildung of assimilation, acculturation, and the polyethnic state" (BM 19). In other words, borderland theory and writing deconstruct the border, turning it from a site of "spatial stereotypes" ( $B M$ 24 ) into a regenerated, rejuvenated interactive, cross-cultural site. This justifies the "omnipresence of pastiche", self-reflexivity and border humour to ironically project the border "culture of the simulacrum" ( $B M$ 33 ), with its new temporal-spatial logic. Chicana romance culture, as reflected in telenovelas, is another dimension of this metafictional, magic realist quality of border writing and cultural theory. The border hybrid genre, therefore, is an amalgam of novel, memoir, national memory, diaspora culture, intercultural theory, pop culture and oral narratives, all deconstructing the fixed canonical imperial genre, together with hegemonic discourse and capitalist consumerism, colonizing and reifying Latina bodies, for instance. Setting, identity and exilic consciousness seem to be interchangeable; permanent residents seem to be replaced by illegal immigrants and undocumented border crossers. Being is replaced by becoming. Los Angeles and San Antonio, in particular, and California and Texas, in general, seem to embody the idea of the "barrio-logos", as expounded by Villa.

\section{Barrio-Logos}

Raul Homero Villa, in his Barrio-Logos, discusses the material and symbolic spaces of Chicano/a cultural recreation (156). He traces the significance of the "space of representation" and the "representation of space" (180) back to the "creative destruction" resulting from founding Anglo Los Angeles on the "ruins of El Pueblo" (19). Villa explains that, using Michel Foucault's term, the "subject formation" of Mexicanos (4) went through various stages: first, the "physical regulation and constitution of space (via legal/juridical state apparatuses and police 
authority" (3). Second, Villa probes the symbolic and intellectual subordination effect of space, as "the ideological control of space (via the interpellation of citizen-subjects through educational and informational apparatuses)" (4). Villa cites as instances of the most "conspicuous subordinating practices active in contemporary barrio life" the production of the "external boundaries of Chicano social space in Los Angeles" (3), "generalized proletarianization" and land loss (4), all 'legally' administered. Barrio-Logos, explains Villa, indicates the "points of intersection and coalescence of effect", "landscape effect, the law effect, and the media effect", channeled through the "three dominating spatial practices" (4). Barrios have been defined as Chicano ghettos, sites of socioeconomic and political marginalization as well as resistance; nevertheless, they played pivotal roles in the development and dissemination of Latino culture in the US (Allatson 30).

"Barrios register the broader social marginalization and discrimination of Chicano/as through counteractive processes of communal formation and the construction of distinct barrio uses of space, and new imaginaries of barrio communal identity" (Allatson 31). "Barriology", as regards Chicano/a culture, "targeted and parodied the epistemological drives by which Mexican Americans had been known and represented in various branches of scholarship" (Allatson 31). "Barrio-logos", according to Villa, "regards barrios as dynamic cultural sites of spatialization governed by a barriorizing dialectic of imposed pressures and internally generated responses on the part of barrio residents to those pressures" (Allatson 31). Barrios "psychologically and materially" sustain the "sense of home location", explains Villa (5). Villa cites attempts to defend Chicano Southside Park as an example of the "barrio's attempts to salvage its cultural, economic, and social integrity against the cumulative devastations" (172).

In these struggles, the persistence and power of memory is crucial, being simultaneously effective, as practically informing history in the politics of community defense, and affective, as emotionally orienting story in the politics of textual representation. Memory, therefore, acts as a common denominator bridging narratives of place in the "real" and represented cities of Chicano barrio dwellers (Villa 235).

The above text is reminiscent of Edward Said's terminology and practical criticism of Conrad and Camus; both Villa and Said share the 
emphasis on the overlapping territories of history and story, the symbolic, ideological and moral geography of space, as well as the spatial metaphors, as related to the text and the world.

\section{The Nueva Mestiza and Chicana Resistance}

As for the "nueva mestiza", it, according to Gloria Anzaldua, is inspired by an earlier concept by Jose Vascocelos ( $C M$ 413). "I am all races", maintains Anzaldua as she defines the Nueva Mestiza:

I am cultureless because, as a feminist, I challenge the collective cultural/religious male-derived beliefs of IndoHispanics and Anglos; yet I am cultured because I am participating in the creation of yet another culture, a new story to explain the world and our participation in it, a new value system with images and symbols that connect us to each other (LF 102-3, stress mine).

Anzaldua significantly introduces La Conciencia de la Mestiza/ Towards a New Consciousness, with a symbolically interlingual poem: "Because I, a mestiza, / continually walk out of one culture / and into another, because I am in all cultures at the same time" ( $L F$ 99). The same lines are then rewritten in Spanish. "As a mestiza I have no country, my homeland cast me out; yet all countries are mine because I am every woman's sister or potential lover", says Anzaldua ( $L F$ 102). Through recurrent references to crossbreeding to mean hybrid and surviving crossroads to signify borderlands, Anzaldua further explains her notion through the analogy of corn:

Indigenous like corn, like corn, the mestiza is a product of crossbreeding, designed for preservation under a variety of conditions. Like an ear of corn, a female seed-bearing organ, the mestiza is tenacious, tightly wrapped in the husks of her culture. Like kernels she clings to the cob; with thick stalks and strong brace roots, she holds tight to earth, she will survive the crossroads ( $L F 103$ ).

The mestiza is steadfast in the earth and deeply-rooted in her heritage; the idea of multiculturalism and hybridity, therefore, is embraced as a point of strength:

The new mestiza copes by developing a tolerance for contradictions, a tolerance for ambiguity. She learns to be an Indian in Mexican culture, to be Mexican from an Anglo point of view. She learns to juggle cultures. She 
has a plural personality, she operates in a pluralistic mode, nothing is thrust out, the good, the bad and the ugly, nothing rejected, nothing abandoned. Not only does she sustain contradictions, she turns the ambivalence into something else ( $C M$ 415, stress mine).

Another analogy is that of the turtle, on whose back she carries the cultural load of heritage: "My Chicana identity is grounded in the Indian woman's history of resistance. The Aztec female rites of mourning were rites of defiance protesting the cultural changes which disrupted the equality and balance between female and male" ( $L F 43$ ). The hybrid mestiza, Indian-Mexican and later Chicana, is the nueva or new identity through which she puts up with all sorts of borders. She refutes the allegation of Chicanas being severed from roots:

"Your allegiance is to La Raza, the Chicano Movement," say the members of my race. "Your allegiance is to the Third World," say my Black and Asian friends. . . What am I? A third world lesbian feminist with Marxist and mystic leanings... Only your labels split me (AR 17).

"Yet in leaving home I did not lose touch with my origins because $l o$ mexicano is in my system" ( $L F 43$ ). Her cultural role is beautifully depicted through the turtle metaphor that resounds in Mohja Kahf's "Men Kill Me", for instance. "I am a turtle, wherever I go I carry 'home' on my back" ( $L F 43)$. Teresa McKenna explains that the divide in Anzaldua is an emotional residue of an unnatural boundary, emanating from the borderlands.

The border woman's body becomes a site of consciousness and politics, McKenna explains; it "becomes the site for inscribing the ambiguity of her history and existence" (115). Anzaldua's poem, indeed, is extremely expressive of the 'barrio-logos', expounded by Villa:

1,950 mile-long open wound

dividing a pueblo, a culture,

running down the length of my body,

staking fence rods in my flesh,

splits me splits me

me raja me raja

This is my home

this thin edge of

barbwire. $^{2}$ 
The Nueva Mestiza inhabits the barrio-logos and "To survive the Borderlands / you must live sin fronteras / be a crossroads" (LF 217). Even as an academic, she is forced to remain restricted in, what she calls, the Nepantla, the liminal, inbetween zone between worlds (AR 239). She is incessantly "caught in the crossfire between camps / while carrying all five races on your back / not knowing which side to turn to, run from" ( $L F$ 216). She is simultaneously "Alienated from her mother culture, 'alien' in the dominant culture, the woman of color does not feel safe within the inner life of her Self. Petrified, she can't respond, her face caught between los intersticio, the spaces between the different worlds she inhabits" ( $L F$ 42). Her psychological conflict is to survive the borderlands and the alien spaces: both Mexico and "the tragic valley of South Texas" ( $L F$ 112). "This land [that] was Mexican once / was Indian always/ and is. / And will be again" ( $L F 113)$.

In Borderlands/La Frontera (1987), Anzaldua excavates for a chain of native female figures and archetypal serpent-like Aztec goddesses; the "Coatlicue state" being "a metaphor for a nueva mestiza consciousness of plural and contradictory selfhood", representing a "feminist Chicana reworking of the goddess Coatlicue state in Aztec mythology" (Allatson 72, 71) who resist the Western rational entrapment of the native woman, in brief, of socially disparaged or marginalized identity. "The Coatlicue state signifies the eruption of repressed and painful memories, and it also denotes a liminal space of self-awareness, la facultad, outside the imposed discourse of Western rationalism" (Allatson 72). McKenna explains that the border woman's body becomes "a reconstruction of Aztec and Chicana histories. By recovering the feminine potential in Coatlicue, she rewrites the history of Chicanos", "affirms the multiplicities represented by the serpent goddess", and "derives a creative center that directs her as a mestiza and as a creative artist" (McKenna 115). Anzaldua disables the Chicana symbolic function as a traitor by merging her with Virgin Mary. Significantly enough, Anzaldua stresses her dark skin, prieta, and sees it as one of her creativity triggers (AR 235): "Inside my skull something shifts. I "see" my face. Gloria, the everyday face; Prieta and Prietita, my childhood faces; Gaudi, the face my mother and sister and brothers know". 3 Psychoanalytically, Anzaldua delineates the reasons behind the patriarchal injustice among Chicanos against Chicanas:

In the Gringo world, the Chicano suffers from excessive humility and self-effacement, shame of self and self- 
deprecation. Around Latinos, he suffers from a sense of language inadequacy and its accompanying discomfort; with Native Americans, he suffers from a racial amnesia which ignores our common blood, and from guilt because the Spanish part of him took their land and oppressed them. He has an excessive compensatory hubris when around Mexicans from the other side. It overlays a deep sense of racial shame (MC 419).

Significantly, Anzaldua links the Coatlicue goddess to the archetypal Jungian trickster figure, in addition to a transformational incarnation of multiplicity, which is processed through her body. This is further linked to her writing and creativity. "I am a wind-swayed bridge, a crossroads inhabited by whirlwinds. Gloria, the facilitator, Gloria, the mediator, straddling the walls between abysses" (AR 17). These notions are, indeed, reminiscent of the metafictional comments of the Mermaid, Alieph, and of Abdelrahman Salahadin as the trickster or Coyote figure in Diana Abu-Jaber's Crescent. Anzaldua maintains that:

When I write, it feels like I'm carving bone. It feels like I'm creating my own face, my own heart, a Nahuatl concept. My soul makes itself through the creative act. It is constantly remaking and giving birth to itself through my body. ${ }^{4}$

And once again I recognize the internal tension of oppositions can propel (if it doesn't tear apart) the mestiza writer out of the metate where she is being ground with corn and water, eject her out as a nahual, an agent of transformation, able to modify and shape primordial energy and therefore able to change herself into turkey, coyote, tree, or human. ${ }^{5}$

Anzaldua suggests that the first step to unsettle the patriarchal vision of the Chicana, or, generally, the Latina, as the archetypal "femme fatale" is "to see Coatlapopeuh-Coatlicue in the Mother, Guadalupe" (CM 419). The Mexican Virgen de Guadalupe is a "spiritual mestizaje" ( $A R$ 229).

'Chicano/a', originally a term of disparagement for working-class Mexican Americans, was adopted as a neocultural, transcultural sign and a collective identity marker by the Chicano Movement in the 1960s (Allatson 61). It indicates Mexican Americans occupying, with their cultural project, the liminal and lexical interlingual space, exemplified 
by English-Spanish code-switching in their literature. Chicano literary space is one of the traits of Chicano/a literature, delineated by BruceNovoa in Retrospace (49). It is a literature of identity exploring its roots in Aztec folklore or Indian heritage as well as of confrontation and protest to exclusion. Most conspicuous complexes of Chicano/as are Texas and California. Chicanismo, therefore, has provided, as an organizing rubric for the main precepts of a new communal identity formed by mestizaje, the sense of belonging to the southwest as a homeland. The Chicana writer, according to Alicia Gaspar de Alba, "is the keeper of the culture, keeper of the memories, the rituals, the stories, the superstitions, the language, the imagery of her Mexican heritage" (Barton and Hudson 67). This is, indeed, exemplified by Caramelo, starting with its title and main symbol, the shawl or the rebozo. Like Arab American writers, Chicano/a authors unsettled stereotypes and resisted discursive hegemony, further embracing their cultural hybridity as a creative inspiration.

\section{Counternarratives through Postmodernist Techniques}

In his Fabulation and Metafiction, Robert Scholes explains that metafiction or "experimental fabulation" (4) blends "concern for storytelling" with "a fresh vision of human problems and aspirations" (218). The "process" itself is important; only two words in a separate line end Scholes' book: "Fabulation lives" (218). In her Parody/Metafiction, Margaret Rose explains that metafiction is a critical demonstration of the processes of producing and receiving fiction from within the literary text (66); this provides self-parody (96) and self-scrutiny as well as reflection and reflexion (107). It is a mirror-image but with contemplation, reconsideration and reproduction. It shows "how a literary work exists both within a particular social context and a literary tradition" (66). Indeed, this narcissistic self-involved, self-reflexive mode of fiction effects a deconstruction of the authority of this same genre together with any 'reality' or authenticity behind it. In A Poetics of Postmodernism: History, Theory and Fiction, Linda Hutcheon explains the postmodernist roots of the simultaneous undermining of the authenticity of both history and the novel in historiographic self-reflexive fiction. Metafiction deconstructs itself, together with the patriarchal hegemony it is trying to dismantle. (Hutcheon, 110).

I have been arguing that postmodernism is a contradictory cultural enterprise... Historiographic metafiction, for 
example, keeps distinct its formal auto-representation and its historical context, and in so doing problematizes the very possibility of historical knowledge, because there is no reconciliation, no dialectic here, just unresolved contradiction (Hutcheon 106).

The genre is an incarnation of Lyotard's notion of the mistrust of metanarratives (Lyotard xxiv), including both history, or 'his-story', and the self-reflexive novel that supposedly deconstructs it. To further prevent, what Coleridge calls, the "suspension of disbelief", magic realism is used to add an aura of mystery and the supernatural that, nevertheless, sounds totally and weirdly realistic. Especially in Crescent, it beautifully highlights cultural hybridity and carnivalesque postcolonial liminality, as embodied by Abderahman Salahaddin, a pastiche of history and pop culture.

\section{Paratextuality and Metafiction: Borderlands of the Text}

In Paratexts, Thresholds of Interpretation, Gerard Genette assigns various liminal devices and conventions, both within (peritext) and outside (epitext) the book (xviii), a hermeneutic interpretive effect. The Epigraph has a hypertextual function of channeling the reader's vision, while typesetting and print techniques as well as discursive notes perform an intellectual and cultural function $(159,34,325)$. It is a calculated "statement of intent" (221) on the part of the author. Typographical choices provide an "indirect commentary on the texts" (34). Furthermore, truthfulness (206) and authenticity, as narrative notions, are clearly undermined through the paratextual subtitle "Puro Cuento", or mere lies, in Cisneros' Caramelo. On the other hand, Cisneros' discursive and historic footnotes perform the function delineated by Genette as "attempts to forestall objections" and "provide additional arguments" (326). Paratexts, indeed, work as a metafictional technique in Caramelo, and as a parallel technical embodiment of the borderland metaphor and the Chicana hybrid identity. Prologues, epilogues, epigraphs, and, most important of all, footnotes, are selfreflexive paratexts employed to deconstruct the authenticity of Lala's narration, Cisneros' own 'historia', as well as the novel genre in general. Footnotes, together with the historical chronology at the end, interpreting events and adding historical background information, work as New Historicist documents. These could be read in conjunction with Lala's main narrative and the stories-within-her-story. Hovering reality, 
therefore, always interrupts the narrative thread and unsettles the authenticity of both Lala as a reliable narrator and Cisneros as an authentic story-teller. Furthermore, they disrupt the fairy-tale like atmosphere induced in the many layers of simulacra. These are created by The Arabian Nights, telenovelas and other pop culture paratexts.

The disclaimer at the very beginning of the novel reminds us of Coleridge's "willing suspension of disbelief"; only here it is willing suspension of belief. Significantly enough, the epigraph at the outset of the novel is derived from the symbolically-entitled Translated Woman: Crossing the Border with Esperanza's Story; both motifs of cultural translation of women, especially Latinas, and symbolic border-crossing underline Caramelo. The epigraph to the novel, "Tell me a story, even if it's a lie", is immediately accentuated by the following prologue: "To write is to ask questions. It doesn't matter if the answers are true or puro cuento", meaning pure stories, here, lies. "After all and everything only the story is remembered, and the truth fades away like the pale blue ink on cheap embroidery pattern" (Prologue to Caramelo). Embroidery is significant since the rebozo, woven by the great grandmother and handed in to the granddaughter, is an extremely significant Chicana symbol. Here the idea is spelt out bluntly: it is merely a lie, even if it is, sometimes, cleverly masked as the truth:

The truth, these stories are nothing but story, bits of string, odds and ends found here and there, embroidered together to make something new. I have invented what I do not know and exaggerated what I do to continue the family tradition of telling healthy lies. If, in the course of my inventing, I have inadvertently stumbled on the truth, perdonenme (Prologue to Caramelo).

Another important paratext is that of the historical chronology at the end of the novel. Besides disrupting the fictional illusion, this appendix works to historicize and contextualize the novel; it is a statement on the frozen, stagnant third-world citizens. This Chronology starts with eyewitnesses' written account on the conquest in 1519 (Caramelo 435), passes with Immigration Reform and Control Act in 1986, and ends with the passage from the Native American belief in the Aztec fertility goddess to the conversion process to Christianity (Caramelo 439). It is interesting that Cisneros makes use of the Chronology to further advance his-story as written by the powerful and victorious. She keeps making fun of narrating historical events, claiming 
that each side undermines the other's narrative as inauthentic. It starts with the ironic tone of "1789: Alien and Sedition Acts bar entry to 'aliens', who jeopardize the peace and security of the nation, as well as making possible their expulsion" (Caramelo 435). Immediately afterwards, the inauthenticity of history writing is spelt out: "1846: US invades Mexico. The Mexican War. Or, the American War of Intervention, depending on your point of view" (Caramelo 435). In a footnote, all italicized, the authenticity of American media is also questioned when, to use Edward Said's term, "experts", , who are brown enough and might pass as authentic representatives of Latinos, speak in the name of Mexicans: "there were hardly any Latinos on TV who were actually Latino and not some payaso pretending to be Latino" (Caramelo 221). The concept is related to the 'native informant' in Hamid Dabashi's Brown Skin, White Masks, itself a reiteration of Frantz Fanon's pioneering book.

\section{Print Techniques, Cultural Translation and the Nueva Mestiza}

Significantly, print techniques like bold or italics further highlight some metafictional comments addressed to the reader. Some of these remarks are related to popular culture, an important motif underlying this and many other Chicana novels, since Mexican soap operas are considered a widely-spread characterizing trait. The following remarks are printed in bold as one of Cisneros' metafictional techniques: "If this were a movie, a few notes of a song would follow here, something romantic and tender and innocent on the piano, perhaps 'The Waltz Without a Name'?" (Caramelo 104). After telling another part of the story, the narrator links her "familia", "Reyes-ness", as she ironically coins a term for her family notion. To further ridicule the familia notion, a bold print of another sarcastic comment is addressed to the reader to highlight the hyperreality of the told story: "Just like a good fotonovela or telenovela" (Caramelo 105). 'Big closely-related families' is another Mexican trait; this, however, is also undermined. Cousins of cousins are distantly related: "Reyes-ness could be detected in their physiognomy, but they had long evolved into separate branches of being" (Caramelo 105).

"The old proverb was true. Spanish was the language of the gods and English the language to talk to dogs", thus ridicules "Spic Spanish" chapter cultural translation, elsewhere designated as politicized too (Caramelo 208). Mexican is also perceived of as an insult so Americans 
would rather say 'Spanish' (Caramelo 210). Polite phrases, varied concepts like 'destiny' and 'destination', a phrase like 'God willing', all are shown to be betrayed in translation; the symbolic import of words like 'negro' is extremely different (Caramelo 209, 211). Chapter titles are extremely funny and significant, even when it comes to the hybrid identity. "All parts from Mexico, Assembled in the US, or I Am Born" (Caramelo 231) is a magnificent example of Cisneros' sarcastic style, even of poignant identity issues. It is significant that while Cisneros opens her novel with an epigraph from an untranslated Spanish song, she, later on not only translates another one but also uses print techniques to highlight the hybridity inside her. There are two columns on two following pages: the first is given to the song in Spanish, then the second column is for the English translation (Caramelo 182-3). Immediately, however, right before the reader identifies with the supposedly real-life story-within-the-story of the lover turned into a priest in this song, Cisneros resorts back to simulacra and hyperreality, as usual, through popular culture. As usual in Cisneros, this is printed in bold: "His life makes a wonderful story and was adapted into that unforgettable film" (Caramelo 183). To further highlight this, it is printed in bold; in other words, the reader cannot miss it. In case the oblivious reader does, another chapter simply spells it out in an extremely funny title: "A Scene in a Hospital That Resembles a Telenovela When in Actuality It's the Telenovela That Resemble This Scene" (Caramelo 402). According to Genette, titular usage is one of the paratexts or the borderlands of the text (213), hence the significant titles of Caramelo chapters. A symbolic text introduces the second part of Caramelo, significantly entitled, "When I Was Dirt". The text blends harsh reality with fairy-tale illusions, Biblical parables with narratives. Funnily, the narrator, Lala, links herself to the archetypal wicked witch with the broom. Again, her reliability as narrator is undermined with the limited human perspective or point of view she offers, all done in a very down-to-earth, seemingly realistic tone, soon unsettled by the fairy-tale atmosphere.

"When I was dirt"...is how we begin a story that was before our time. Before we were dust and to dust we shall return. Ashes to ashes, dust to dust. A cross on our forehead on Ash Wednesday to remind us this is true... When I was dirt is when these stories begin. Before my time. Here is how I heard or didn't hear them. Here is 
how I imagine the stories happened, then (Caramelo 89, stress mine).

This, therefore, clearly undermines the authenticity of Lala, the main narrator and the one through whose consciousness all narratives are filtered. Indeed, any attempt at identifying with Lala or any of the other characters is always disrupted by constant reminders of external reality, like the footnotes device.

\section{Footnotes, the Rebozo and Pop Culture}

Use of footnotes, as a technique skillfully disrupting reality, is another metafictional device. Both the narrator Lala and the footnotes address the reader in an extremely self-reflexive manner; print techniques further accentuate the relationship. Even when the reference is to epiphany of Virgin Mary, there is this questioning note that "honest to God, this sounds like a lie, but it's true" (Caramelo 389). What follows is like an epigrammatic pithy saying, with the rebozo as emblematic of the patchwork of the multicultural American identity: "The universe a cloth, and all humanity interwoven. Each and every person connected to me, and me connected to them, like the strands of a rebozo. Pull one string and the whole thing comes undone" (Caramelo 389). Furthermore, print techniques are clear in the bold font of the analogy of the story-withinthe-story and the famous Mexican soap operas, a motif underlying the whole novel. Here, however, the link is to Hollywood, with another reference to how Mexicans and Mexican Americans are depicted in Hollywood. The interruption is definitely printed in bold: "So this part of the story if it were a fotonovela or telenovela could be called Solamente Soledad or Sola en el mundo, or I'm Not to Blame, or What an Historia I've Lived" (Caramelo 95). This statement needs a footnote, all italicized, to further explain pop culture references and link them to historical events, definitely addressing the reader throughout:

I forgot to mention, Maximiliano was ousted by none other than Benito Juarez, the only pure-blooded Indian to rule Mexico. For a Hollywood version of the aforementioned, see Juarez, John Huston's 1939 film with the inestimable Bette Davis, who else, the madwoman (Caramelo 96).

Pop culture is a recurrent motif that adds another layer of hyperreality to the novel, undermining any authenticity of the told story as well as the reliability of both narrator and author. The phrase "Just 
like a good fotonovela or telenovela" (Caramelo 105) recurs like a refrain throughout the novel, mostly printed in bold letters. Ironically, to unsettle both Hollywood and the Mexican Revolution itself, a footnote, supposedly explaining the Mexican Revolution to the reader, suddenly wakes him up to the ridiculous simulacrum, out of which people might get historical information. Hollywood movies, with all their stereotypes and anachronism, seem to be deemed an "authentic" source, even to younger generations of Chicano/as, who are not in close contact with Mexico. The figure tackled here is a controversial figure, considered by some a hero, "fighting for ancient land rights", by others "dubbed rebels" (Caramelo 152). The film director, however, is a famous one, let alone the John Steinbeck as the screenplay writer. Again, the footnote is all italicized:

For a Hollywood version of the Mexican Revolution, see Elia Kazan's Viva Zapata. John Steinbeck wrote the screenplay. His choice for the lead role was none other than the Mexican movie star Pedro Armendariz, featured in The Pearl. Armendariz had the sexy, indigenous looks for the job, and, more importantly, the acting skills, but was unknown in the States. Kazan, however, wanted and got Marlon Brando for the part, who, in my opinion, looks ridiculous with his eyes taped slant trying to pass as Mexi-Indian (Caramelo 152).

The verb "pass as" is extremely significant, though usually used for minorities doing their best to pass as mainstream to avoid racial profiling and stereotypes. The fact that the Mexican actor, though a star in Mexico, was not cast for the role because he was not known in the US, is another critique toned down by being framed within pop media context. There is a patchwork of American, British and Mexican pop culture that suggests a way out of the conflicting showdowns; it significantly comes right after "an invasion of illegal aliens" statement: "Hippies and vagabond anthropologists, artists, students, foreigners, ... the Beatles, the Rolling Stones, Bob Dylan, the wives of politicians, . . . came to see Maria Sabina", who was "a holy relic" (Caramelo 195). Like Selena, Sabina unites people from all walks of life and cultural affiliations.

Another footnote explains the cultural and symbolic import of the most important emblem, also the title of the novel, the "rebozo" . This, in a caramel colour evoking skin tone, could be taken as an emblem of the Mexican cultural heritage. "Soledad cleaned Narciso with her 
caramelo rebozo, wiping that beautiful face" (Caramelo 104). The rebozo is linked to Disney's Mermaid and the Snow Queen, another pop culture symbol, perceived in conjunction with Mexican cultural heritage and reality: "Even with half its fringe hanging unbraided like mermaid's hair, it was an exquisite rebozo of five tiras, the cloth a beautiful blend of toffee, licorice, and vanilla stripes flecked with black and white, which is why they call this design a caramelo"; "A rebozo as cradle, as umbrella or parsol" (Caramelo 94). Significantly, the "unfinished caramelo rebozo" (Caramelo 154) or shawl was reduced to a plaything and almost forgotten until it was handed down to Lala from her grandmother. It is reminiscent of the quilt as emblematic of African American heritage in Alice Walker's "Everyday Use".

An extensively-detailed cultural note on the cultural significance of the shawl naturally follows in the footnote, further disrupting any possible illusion or belief in the evoked fairy-tale atmosphere. In this historical note, Cisneros, like many Chicano scholars, links Mexican Americans to Native Americans. The footnote, all italicized, acts very much like an anticlimax that ruins any identification on the part of the reader:

The rebozo was born in Mexico, but like all mestizos, it came from everywhere. It evolved from the cloths Indian women used to carry their babies, borrowed its knotted fringe from Spanish shawls. . . The quintessential Mexican rebozo is the rebozo de bolita, whose spotted design imitates a snake-skin, an animal venerated by the Indians in pre-Columbian times (Caramelo 96).

Paradoxically, soon after, in another footnote, the author informs the reader that the rebozo might have been a suicide or murder tool for Ambrosio in Arizona: "the rumour that he was strangled with one of his own black rebozos is true (by his second wife. . .), or committed suicide by hanging himself from the rafters with an especially beautiful silk rebozo de bolita, well, who knows and ni modo. But that is another story" (Caramelo 102). Another cultural role of the rebozo is made fun of as terribly ridiculous: to tell the world "I am a widow" or even worse: "And when she does marry, how her mother would place a pale blue rebozo on her head, meaning, This daughter of mine is a virgin. . . Unused merchandise" (Caramelo 105); the blue is a clear reference to Virgin Mary's blue veil. The rebozo even has a language that has to be explained to foreigners (Caramelo 102). In the final paratext, the 
supposedly-historical Chronology, the second entry historicizes the rebozo as dating back to 1572, "the first published mention of the rebozo" (Caramelo 435). Historicizing or contextualizing is also a resistant technique unsettling hegemonic discursive and textual strategies; nevertheless, even this is deliberately shown to be inauthentic. His-tory is after all only a human construct.

\section{'Merican' as Border Trope: Interlinguality and Historicity}

"Merican", coined by Cisneros and indicative of her hybrid interlinguality conept and device, was first used in her short story "Mericans" in Woman Hollering Creek, as related to the Awful Grandmother, an emblem of filiative hegemony and restraint (20). As explained, Cisneros plays with bold, italics and other printing techniques to stress what she focuses on. Since the whole footnote above is deliberately italicized to further highlight severing the reader from the told story, 'rebozo' and 'that is another story' are accentuated by not being bold. Elsewhere, in "the Grandmother's toffee-striped caramelo rebozo, which he wraps around himself like a flag (Caramelo 378), 'caramelo rebozo' is definitely italicized not as a foreign language but as a symbol that needs to be highlighted. This is always the case with stories-within-the-story, in addition to anything she likes, regardless of inserting another language and italicizing it. The fact that she does not italicize Spanish is indicative that this is her language; code switching here is essential. She never translates Spanish; the reader should do this for himself. Interlingualism is extremely significant for Chicano/a writers; it has to do with the hybrid identity. Significantly, it is neither hyphenated nor dehyphenated; 'American' is no longer there, as in Arab American, for instance. It is one step further: it is simply 'Chicano'. This is linked to the loss of home after the Mexican Revolution: "Later she will learn there is no home to go back to. The Mexican Revolution begins, and Ambrosio Reyes is conscripted by Obregon's troops and never heard from again" (Caramelo 102).

The novel is abundant in historicizing footnotes: one explaining to the reader the Mexican Revolution (Caramelo 152), another discussing World War I and II, a third one commenting on "the invasion of illegal aliens" (Caramelo 195). Indeed, the word 'alien' infuriates Mexicans, together with 'illegal', since they believe they have a right to parts of this land. One of the most famous refutations is: "we did not cross the border; the border crossed to us", a clear reference to them as 
well as to Native Americans too. The border becomes emblematic of trans-American, subalternized identity, according to Jose David Saldivar, accredited to be the founder of US-Mexico border studies. In TransAmericanity, Saldivar discusses the construction of subalternized identities, arguing how transnationalism is contested in Caramelo:

Inocencio's conversion from Greater Mexican infamy, from illegal Mexican to what Cisneros wryly calls ethnic "Merican", can never be complete, and like the caramelo rebozo he wraps around himself "like a flag", it becomes an integral part of the postcolonial present (154).

The compound adjective "Merican", coined by Cisneros, is a magnificent amalgam that verges on both borders, explaining hybrid identity. Since the narrator is unreliable and the author inauthentic, details like being forced to enlist or volunteering to do so to become a US citizen are meant to confuse the reader about hybrid identity and compromizes made by Mexican Americans. Again, the subtitle of the novel recurs: "Is that what he told you?" "Puro cuento", meaning pure lies, "he wanted to enlist" (Caramelo 418). This, therefore, undermines the father's tale, exactly as the grandmother's and Lala's tales are inauthentic: "Uncle, drive me to the enlistment center, I want to become a US citizen. I want to become a US citizen" (Caramelo 418). All narrators are simply unreliable.

Sometimes, historical background information is interwoven within the body of the novel, always linking Reyes story to historical events, together with linking Mexico to the US:

Inocencio Reyes had the misfortune to grow up in interesting times and witness the beginning of Mexico's Golden Age. While the U.S. suffered its Depression, Mexico was undergoing its finest decade (Caramelo 205). The new mestizo/a identity, proud of its Indian heritage, was, in the meantime created, with nationalization of oil companies and the flourishing arts. Very soon, however, Mexican workers were to harvest US crops and participate with the Allies in small operations (Caramelo 206). As if this historicizing is not enough contextualization, another detailed footnote immediately follows with the exact number of Mexican fighter pilots during World War II (Caramelo 207). Again, in the same footnote, pop culture tones this down: "For a super-sentimental story of Squadron 201, see Indio Fernandez' splendid Salon Mexico, a classic. Note the Mexican matriarchy scene between the injured pilot and his 
angelic mother. This scene alone will explain everything" (Caramelo 207). Indeed, like heritage, story-telling and pop culture, matriarchy is extremely important in Chicana literature. Ironically, the "Awful Grandmother" in the novel is the exact antithesis of the melodramatic and sentimental, in Cisneros' opinion, "angelic mother" in Fernandez' classic in the above footnote. As explained earlier, it was because of Gloria Anzaldua that the positive connotations of Virgin Mary came to replace the Jungian archetype of the wicked witch or the femme fatale, as the elevated trickster figure came to symbolize the resistant smuggler of illegal immigrants across the border.

\section{Arabian Nights and Lala's Self-Reflexive Counternarrative}

The Arabian Nights works as a self-reflexive counternarrative in Caramelo. In a footnote, the famous Mexican telenovela is seen as the present-day Shahrazad; indeed, most writers of this well-loved pop culture genre are women writers and, in many ways, voice women's opinions. Even if this form is looked down upon by some as low culture, it does empower women and narrate their struggles, at least to people who do not derive their knowledge from archives, documents or written literature. In a way, fotonovelas act like an archive of oral narratives nowadays; in a footnote towards the end of the novel, Cisneros explains that the telenovelas are the simulacrum and not the other way round; their importance is that they keep the heritage alive since they act like modern-day Shahrazad. Again the printing technique is used for emphasis; since footnotes are italicized in Caramelo, "telenovela" is the only word that is not italicized so it stands out:

A famous chronicler of Mexico City stated Mexicans have modeled their storytelling after the melodrama of a TV soap opera but I would argue that telenovela has emulated Mexican life. Only societies that have undergone the tragedy of a revolution and a near century of inept political leadership could love with such passion the telenovela, storytelling at its very best since it has the power of a true Scheherazade, it keeps you coming back for more. In my opinion, it is not the storytelling in telenovelas that's so bad, but the insuffereable acting (Caramelo 409).

Afterwards, the rest of the footnote explains that what undermines these soap operas is their implausibility; only the credulous would believe 
them and take them to be true; nevertheless, nothing seems authentic or rings true in Cisneros' opinion. On the other hand, with the several stories incorporated within her story, Lala, the narrator of her grandmother's story, is implicitly compared to Shahrazad. Ilan Stavans sees the rebozo as harking back to Andalucian heritage and relates it to Lala, seeing "herself as a present-day Scheherazade and Caramelo is her Thousand and One Nights" (Stavans 57).

Lala's is, in fact, one of the multiple points of view in the novel. There are multiple perspectives, all intersecting and overlapping, sometimes, even questioned like that of the Awful Grandmother (Caramelo 91, 123, 262, 348, 359). Like the footnotes, The Arabian Nights framework, acting like embedded texts, and the non-linear structure further serve the disrupting purpose. They both portray the family saga that revolves in a kind of vicious circle, itself mirroring Chicana/o history. "Because a life contains a multitude of stories and not a single strand", says Lala (Caramelo 115). The fact that Narciso tells his story in Chicago, as a setting, (Caramelo 137) is enough evidence of the Chicano/a barrio-logos, discussed by Villa. Furthermore, the narrative of Narciso, as related to the grandmother, seems to bear the seeds of its own destruction (Caramelo 143). In Trans-Americanity, Saldivar adds another portable barrio-logos: the Barrio Archive Shoebox (TA 180). It is the acquittal evidence that the Father is not an undocumented immigrant or illegal alien as the indispensable identity shoebox or the paper "barrio archive" (TA 180) prove that Inocencio was honourably discharged from the US army after fighting and defeating its enemies: Europe's Fascists during the Second World War. Saldivar likens the function of this American identity box to the Mexican rebozo, both being "barrio archives" on both sides of the border (TA 181).

The paper archive, like the rebozo that is passed down through the Reyes family, is figured finally by Celaya as the supplementary "trace" of early migratory (immigrant) life, an "outernational" trace that paradoxically stands in for a loss of history yet simultaneously marks the figurations of Greater Mexico, a Mexican community de adentro (from within) that commences with the investment through puros cuentos and memory, in that melancholic loss (TA 181).

Indeed, it could be an allusion to Narcissus, the mythical arrogant, and self-centred figure; it acts like an alter-ego or surrogate self to writers or 
narrators, with their obsessive and somehow hubristic, love of their own creativity and perfection. The "border-crossing puros cuentos and histories" are, therefore, both spatial and discursive that can neither be assimilated nor translated (TA 181). If Edward Said ${ }^{8}$ deconstructed the ideological geography of the canonical novel, Cisneros, according to Saldivar, does this by merging genres and producing the mestiza or hybrid high and low culture type of novel/telenovela, in other words, imperial/Mexican. All is done through paratexts and other narrative techniques in which, what he terms, the "mass-mediated" "transnational novel" (TA 181) abounds:

Cisneros permits the introduction of a critical study of cuentos and discourse where space and rhetoric are entwined and where rhetoric depends on space. Can space act on style, producing a double enunciation (toward the novel and the telenovela)? Near the US-Mexican borderlands, does figurality go up and across? Geography indeed acts on style in transnational novels about Greater Mexico such as Cisneros's Caramelo or Puro Cuento (TA 181).

\section{Drowned Arab: Hollywood and Arabian Nights in Crescent}

Similarly, The Arabian Nights acts as subtext, glimmering beneath Crescent. As in Caramelo, the disputed and much-quoted text is inextricably linked to popular culture, specifically, Hollywood. Sirine's Uncle insists on every single minute detail of the slave narrative of Abdelrahman Salahadin. His fake drowning show to escape slavery (Crescent 64) and his career at Hollywood like Omar Sharif are told in a magical realist atmosphere with the presence of the Mermaid and jins all around. The characters' names in the story-within-the-story evoke the types of a morality play: the Covered Man (Crescent 65) and the Drowned Arab, evoking the stereotypical lens Arabs and Arab Americans are perceived through. "So Abdelrahman Salahadin had enough with drowning. He would try his hand at being a movie star"; "He played Mexicans and Italians and that sort of thing" (Crescent 336). Funnily, Hollywood for him was the Arabic homophone Hal'Awud. This attempt to stop drowning follows the apocalyptic climactic moment of Han resigning and going back to Iraq. It deceptively seems like a respite from the horrors of border crossing from Jordan to Iraq (Crescent 392) and the dictatorial state there. When Abdelrahman Salahadin went to 
audition, "all the Italian actors fell silent" and the line he was saying was significantly "A small, barbaric people!" (Crescent 337). Though "his voice split open the air of the theater like a spear and everyone knew that he would be the star of the movie" (Crescent 337), he was turned down. He had no idea that "no one in Hollywood wanted anything to do with an actual Arab" (Crescent 336). Immediately afterwards comes the comment of the story-teller, Shahrazad in this case, Sirine's Uncle: "Except, of course, how could he be the star, this Jordanian, Syrian, Lebanese, Egyptian, Iraqi, Palestinian, drowned Bedouin of an Arab?" (Crescent 337).

It is logical and natural, therefore, that the lines between the 'Drowned Arab' and the 'Found Arab' are eventually blurred so the story-within-the-story merges with the frame story, the Arab with the Arab American, 'being' with 'becoming' Arab, and the "cultural identities with the dominant constructions" (Gana 240).

[W] hen Han emerges in Iraq bearing the name of the same mythical figure of the uncle's story, i.e., Abdelrahman Salahadin, it becomes of particular relevance to an understanding of the competing mythical, historical, and cultural forces that factor in the makeup of an Arab and an Arab American identity. When Han reappears in Iraq under the name of Abdelrahman Salahadin, not only does myth merge with reality, but also reality itself (here Arabness) becomes too unstable to brook any prediscursive or operational locus of referentiality (Gana 239).

Very soon, an epiphany dawns: "Back in the Forbidden Temple of the Queen of Sheba, also known as Hollywood, California, Abdelrahman Salahadin was tiring of pretending to be a movie star" (Crescent 382). This anagnorisis leads him to go to Cairo to play the role of Othello. Indeed, Abu-Jaber, in the interview included amongst the indices at the end of the book, explains how her original novel was a reworking of Othello, writing back at the racism she sees in the original; afterwards, she rewrites her novel and this is the only remnant of the Othello motif in it. The drowning motif is obviously linked to the fragmented narrative Salahaddin is trying to offer. This is reminiscent of Ihab Hassan's allusion to the metaphorical dismemberment of Orpheus and his lyre in postmodernist literature, only here with specific resonance in Arab and 
Arab American high and pop culture. No matter how dismembered or drowning, Arab American literature still rejoices in the sinking melody:

Postmodernism ... is essentially subversive in form and anarchic or eclectic in its cultural spirit ... Orpheus is not only dismembered; his severed head seems to sing of sinking even as it sinks into the river Hebrus (RC 113, stress mine).

Since "Orpheus consents to dismemberment", to Hassan, this is "the true meaning of the avant-garde" and the postmodern ( $D O$ xvii). Therefore, the drowning motif is clearly linked to postmodernist techniques, such as magic realism and pastiche, mostly embodied by the anti-hero Abderahman Salahaddin, a far-fetched parody of the historic figure Salah Eddin el-Ayubbi, on one level, and of Omar Sharif, on another level. Both high and pop culture beautifully merge in the pastiche or the subscript parodying the original figures, the failed simulacrum, as well as the prsent counternarrative. Paradoxically, as Ingeborg Hoesterey maintains, this pastiche is a postmodern technique that simultaneously pays homage and deconstructs, dialogically engages with and critques both parodied sides (Pastiche 95, 85).

\section{Magic Realism and Rewriting the Slave/Exile Narrative}

Aunt Camille's generational story about her search for her son, Abdelrahman Salahadin, the drowned Arab, opens almost every chapter. Aunt Camille turns out to be the Muse inspiring Sir Richard Burton's translation of The Arabian Nights.

Aunt Camille began to take up space in Burton's imagination. Like a creature leaving a chrysalis, she began the metamorphosis from slave to muse...

"And afterwards." He had begun his famous, criminal, suggestive, imperial version of Victorian madness dissolved in the sky over the Middle East, his translation of The Thousand and One Nights (Crescent 123, stress mine).

Abu-Jaber's statement on the intentional cultural translation, on the part of Burton, is crystal clear in the above text. Furthermore, it is here too that a revisionist version of the slave narrative is offered; this is done, however, within the magical realist atmosphere. The vast difference between the creative and innovative Aunt Camille and the materialist, possessive Richard Burton is done in an ecocritical way: the way she is 
very much at one with nature and relates to every single minute detail of the landscape, while he does not even heed it. Like Cisneros, this is emphasized through interlinguality through the archetypal motif of "Be it" or kon fayakon:

She hears the sound of leaves on leaves and that sound is a word and the word, she says, is aujuba, wonder. She watches the way nightingales and the hummingbirds spin around the garden like spirits and shadows. You may have guessed that she wasn't much of a slave, but that was of little consequence to Burton, who, remember, was just an amateur, and enjoyed collecting people just for the sake of collecting. He adorned himself with Arabs, Chinese, and Indians, and he wrote and wrote and wrote, trying to fill the empty space inside him with a layer of ink (Crescent 122, stress mine).

The verbs 'collected' and 'adorned' explain the urge to write his own story and colonial vision of the tales from the point of view of a someone who comes close to a slave trader; story-telling here is not passive but a constructed Orientalist vision that serves to fill the void inside him. The coming text evokes Saidian typical description of Orientalists:

Sir Richard Burton wandered the Arab world like a speckled wraith. He dressed in native garb, spent hours gazing into Arab eyes... He did, however, like so many Victorians, have an aptitude for ownership, an attachment to things material and personal, like colonies and slaves, he especially enjoyed owning slaves while living in someone else's house. He was an amateur slaver but he was a professional amateur, wearing the robes of so many different tribes, eating the food and entering the land of so many different countries (Crescent 121, stress mine).

The metafictional note that "he wrote and wrote and wrote" to fill the void inside him is reminiscent of Cisneros. Metafiction, in both writers, undermines the authenticity of the imperialist cultural translation of the other, in brief, the Orientalist narrative, only to broaden afterwards to unsettle the reliability of the narrator and of the novel itself in Cisneros, in an attempt to undermine reality and its multiple untrustworthy perspectives. 


\section{Interlinguality, Metafiction: Alieph Reinscribing Narrative}

Magic realism is skillfully used with every single minute detail told in an extremely realistic way, even when this involves the Mermaid Alieph, who is no longer silent and passive but vocal and independent. Significantly, Alieph, who chooses writing to other imposed tasks, joins forces with Aunt Camille, the Muse. To accentuate the power of language, here, Arabic language, she goes on musing on the separate letters, horouf moqatta'a, a concept that has always symbolized the genius of the Quran and of the Arabic language in Islamic tradition. When Aunt Camille asks her how many Mermaids there are altogether, she symbolically cites the number of the Arabic letters: "Twenty-eight. Alieph, Ba, Ta, Tha, Jeem...' and she went through the whole alphabet" (Crescent 271). Like Cisneros, Abu-Jaber does not always italicize Arabic letters, or phonemes here, in a self-assertive attempt to indicate equality in interlinguality. If the reader does not get the meaning, he has to go and look them up. On the other hand, this is reminiscent of another Arab American work that is totally based on the idea of separate and combined letters, and on dotting and diacritics; this is I'jaam by Sinan Antoon. In Crescent, the mermaid Alieph starts to lament that some of the letters are "literalists" and that "we can just barely hear the sounds of the great missing civilization that is said to be lost somewhere in the distant heart of the center of the center, where no one ever goes" (Crescent 272). The postcolonial notion of centre and periphery is obvious.

Furthermore, this might be a reference to, specifically, the Andalucian, or to Arab civilization, in general. Textual evidence is scattered around the novel, varying from fantasy and nostalgia to historical and factual (Crescent 79, 119, 323); the main motif is, what Nouri Gana calls, "convivencia" and what Edward Said calls "serendipity". Even the land is called "Na", which is an allusion to $n a$ elfa'elin, in Arabic grammar, or a longing to the Arabs as agents or makers of civilization or, at least, a nation that should take action for a change. Alieph decides to start with herself and take action; she shrugs her tail and decides to fulfill her urge to write; after all, like many Arab American writers, she left her land to pursue this dream. "Read the book" is another Islamic allusion, while the Arab American writers mentioned in the coming text are preoccupied with writing either novels or autobiographies. 
"I left my sisters and my land," she said. "Because after the narwhale and I read that book I realized that in my heart of hearts I was a poet, not a shipwrecker. I came here to try and write but people keep bothering me about special favors. Half of them are working on their novels, the other half on their memoirs (Crescent 279, stress mine).

Indeed, all the stories abound in metafictional hints. It is not only Alieph's or Aunt Camille's stories that are metafictional. Both uncles of Han and Sirine are professors of Arabic literature at UCLA; writing is part and parcel of their career. Indeed, the choice of this specific university, as indicated in one of the paratexts or indices at the end of the book, is itself an autobiographical detail. Significantly, however, the male narrators, Sirine's Uncle (Crescent 26, 255), Han (Crescent 80, 83), and Han's Uncle (Crescent 243), only acquire Shahrazad's voice through the renarration of Sirine herself. Everything is filtered through her consciousness. In a sense, like Sirine's and Diana Abu-Jaber's father, the male characters acquire the role of Shahrazad, only temporarily, nonetheless, until the counternarrative is revisited and revised by Sirine or Diana Abu-Jaber, the original Shahrazad. The main link of all the stories-within-the-story is the narratee, Sirine, who is addressed by all the narrators. Indeed, the stories turn out to polish her sense of her Iraqi identity and link her more to her Arab side, besides her Irish American one. Salahadin's is the main story-within-the-story told by Sirine's Iraqi Uncle. In addition, there are other narrators of stories-within-the-story like Han himself and his Uncle. On the other hand, Crescent abounds in instances of interlinguality $(26,44,72,80,103,122,242)$, all serving a metaphorical border-crossing role, a function similar to that in Cisneros' Caramelo.

\section{From Andalucía to Drowned Arabs}

In the above nostalgic text, Ariel, the Mermaid, was lamenting the passing of Arab glory (Crescent 272). The drowned Arab motif works like a statement on the decline from Andalucia to the present-day predicament of Arabs: Covered, Drowned, Found or Returned at the end. Nouri Gana explains the symbolic significance of both segments of Abdelrahman's name, as related to the gravity of history and the symbolic import of the motif of Andalucía. This is nostalgic and dreamy at times, especially on the part of Han, and derogatory at other times, on 
the part of some Western historians. The nostalgia and lamentation of past glory are clear, for instance, when Han links the etymology of words to Arabic ones: "It was from when the Arabs came into Spain a million years ago" (Crescent 323) and when he plays songs and reads poems reviving Andalucian glory (Crescent 119). The title "crescent" could be a symbolic allusion to his fantasizing about the prominence of Arab and Muslim civilization once more. Significantly, Han's face has a "crescent-shaped scar at the corner of his eye" (Crescent 393, 84). At the end, pop culture and magic realism are linked to the crescent symbol as Abdelrahman Salahadin's fantasizing about a huge crescent looming in the sky above, what he calls, hal a'uod, or Babylon, nicknamed, according to him, Hollywood (Crescent 320).

Abdelrahman in Andalusian history refers to the Umyyad emir [prince] who escaped the Abbasid massacre of his ruling family...A year later, he became the founder and governor of Cordoba; he declared himself emir of the Iberian Peninsula and began to build the early glory of Al-Andalus (Gana 239).

Gana even links him to the following Saqr Quraish under whose reign, Andalucia was a cultural radiation centre. According to Maria Rosa Meocal,"This was a chapter in Europe's culture when Jews, Christians, and Muslims lived side by side and, despite their intractable differences and enduring hostilities, nourished a complex culture of tolerance" (Gana 239). The second segment of the Drowned Arab is a clear allusion to Salahadin Al-Ayyubi, who "A great warrior, Salahadin respected and earned the respect of Richard the Lion Heart, King of England (Gana 239). There is evidence that Abdelrahman Salahadin acts like Han's alter-ego or surrogate self (Crescent 394); it is calculated that the drowning, covered and returning Arabs are all interchangeably used at the end, as an allusion to the archetypal motif of drowning and of the Celtic Fisher King. It can be read as a reference to the impotence of Arabs, the loss of their holy grail, and their current waste land.

\section{The Barrio-logos of the Nueva Mestiza}

Sirine acts as the Nueva Mestiza or the new hybrid woman and UmNadia's restaurant acts like the barrio-logos or the meeting place of Arab Americans, together with other minorities. Victor represents Chicano workers, while Christobal represents other Latino Americans. Significantly, it is Victor who breaks in the good news at the very end 
that Han is still alive and hands Sirine the phone to answer Han's call: "Victor Hernandez is on the phone, saying Han's name and looking at her" (Crescent 395). The circular structure reminds us of the beginning of the novel when Victor is also the very first witness to the budding love story, starting in the kitchen during the baklava scene (Crescent 21). It is also Victor who links the American dream and its distortion to border crossing and the state back in Mexico (Crescent 323). The distortion of the American Dream is further linked to the American foreign policy in Iraq (Crescent 328). Though Sirine has professionally cooked international recipes at French, Italian and Californian restaurants, she cooks specifically-delicious Arab meals at Um-Nadia's café.

But when she moved to Um-Nadia's café, she went through her parents' old recipes and began cooking the favorite, but almost forgotten, dishes of her childhood. She felt as if she were returning to her parents' tiny kitchen and her earliest memories (Crescent 22).

If cooking brings Sirine and Han together and they have their first date immediately after the baklava-making scene, food links the students to their home: "baklava is important, it cheers the students up" (Crescent 66), says Sirine. Um-Nadia's restaurant is not only a Lebanese one but an all-Arab and Middle-Eastern one because of Sirine's cooking, though she herself, as Han tells her, looks "all-American" (Crescent 20, 76) and many Middle-Eastern students dream of having her as their 'American' girlfriend (Crescent 83).

And the customers quickly returned to the restaurant, only this time there were many exchange students and immigrants from the Middle East. Sirine rolled out dough early in the morning in her open kitchen behind the counter and discreetly watched the students sipping coffee, studying newspapers, and having arguments. Everything about these young men seemed infinitely vulnerable and tender (Crescent 22, stress mine).

Um-Nadia's café, therefore, is the exemplary barrio-logos, where food, pop culture, and heated intellectual and political debates make it the most vivid even for the Iranians of Teherangeles (Crescent 28), the popular name of the neighbourhood, despite the Iran-Iraq war that antagonized them at one time. "Life is an argument!", Um-Nadia wisely explains to Sirine "what they are fighting about" (Crescent 24). Again, 
the parallel structure, overlapping every now and then beautifully renders this. Sirine, busy chopping eggplant and stirring leben, watches closely Hanif Al-Eyad, or Han, as he is busy arguing with students. With light rays reflected on them, the halo effect of the entourage, or the students always surrounding Han, is accentuated.

There are voices blurring and unblurring, complicated gestures, winding hands and arms. It sounds like the same sort of argument the students are always having: about America, the Middle East, and who is wronging whom, this time it's in Arabic, sometimes it's in English, usually it's a little of both (Crescent 24, stress mine).

Even Han's English accent, as perceived by Sirine, is described in culinary terms: it "has nuances of England and Eastern Europe, like a complicated sauce" (Crescent 24). The sometime parallel, sometime overlapping structure best describes the rhythmical movement in a very musical way. "She has turned from the leben to the eggplant when Hanif bursts into English, 'Of course I love Iraq, Iraq is my home, and there is, of course, no going home', and then back into Arabic" (Crescent 24). When the heated argument relaxes into laughter by Han, followed by his students, tabbouleh salad soon follows, implying a happy mood (Crescent 25).

\section{Pop Culture at the Barrio-Logos}

Besides food and the intellectual debates taking place at Um-Nadia's café, television Arabic shows and soap operas form another link to homeland. Funnily, some Americans have even fallen in love with some Gulf series; whether this is due to an Orientalist infatuation with the different and exotic or out of real admiration for the story, it does not really matter, as long as the sharing concept is there:

There are two American policemen, one white and one black, who come to the café every day, order fava bean dip and lentils fried with rice and onions, and have become totally entranced by the Bedouin soap opera plotlines involving ancient blood feuds, bad children, and tribal honor. (Crescent 23, stress mine).

Pop culture is linked to food, since both act as objective correlatives for human culture and heritage. 
As in Caramelo, the postmodernist parodic element of pop culture seems like a unifying human element, perhaps as an escape from life's problems.

At Nadia's café, there is a TV tilted in the corner above the cash register, permanently tuned to all-Arabic station, with news from Qatar, variety shows and shopping channel from Kuwait, endless Egyptian movies, Bedouin soap operas in Arabic, and American soap operas with Arabic subtitles. There is a group of regulars who each have their favorite shows and dishes and who sit at the same tables as consistently as if they were assigned. There are Jenoob, Gharb, and Schmaal, engineering students from Egypt; Shark, a math student from Kuwait; Lon Hayden, the chair of Near-Eastern studies (Crescent 23 , stress mine).

The names Jenoob, Gharb and Schamal, like Covered Man and Drowned Man, are ironically reminiscent of characters as types in morality plays. However, they seem to undermine the rigid dichotomies of the Orientalist East-West oversimplistic binarism. The cardinal points connote that within the 'East' and within the Arab World, there are incredible diversity and multiculturalism that are totally glossed over in grouping them all together in one stereotypical 'bunch'. Abdelrahman Salahadin, the coyote or trickster of the story-within-the-story, is also likened to Omar Sharif since the former dreams of a Hollywood career like the one the latter star has had.

Significantly, the Chair of the Department of Middle Eastern Studies does not make enough money; it is his wife, the Hollywood producer and director who affords their wonderful house on Beverly Hills (Crescent 45). Sirine has always described home in terms related to the American Dream Puritan work ethics (Crescent 132); the same ideal is accentuated in the interview, included as one of the paratexts or indices at the end of the book. A long discussion of Cairo as an intellectual radiation centre in the eyes of young Han and the current ideals of pop culture is expressed in the symbolic smoke and mirrors analogies. "I came back from Cairo obsessed with just about everything cultural, literature, painting, drama. I wanted nothing to do with what I said were the 'betrayals' of religion and money" (Crescent 329-330). Later on, Han was exposed to two views of America: his own of the intellectual, literary America, symbolized by, for instance, his icon, the 
"writer and visionary" Hemingway, versus that of his school friends: "that America was the great traitor, consuming goods and resources, and never really giving anything back but baubles, cheap entertainment. Smoke and mirrors" (Crescent 329). The latter was amplified in his mind through his reminiscence and grasping of the significance of the "street signs in Baghdad", "Disney characters and American-style T-shirts everywhere. Trinkets. Junk" (Crescent 329), reminiscent of Baudrillard's view in his book America (114).

\section{Native Informant and Postmodernist Paranoia}

Like Caramelo, Crescent includes references to, what Hamid Dabashi calls "the native informer" rather than "informant" in his Brown Skin, White Masks, itself a replay of Frantz Fanon's Black Skin, White Masks. Dabashi explains that the term native informant was first used by Adam Shatz in reference to Fouad Ajami.

I have modified informant to informer. Where informant credits comprador intellectuals with the knowledge they claim to possess but in fact do not, informer suggests the moral degeneration specific to the act of betrayal. The record of Fouad Ajami and Kanan Makiya, two prominent native informers who predicted that in response to the US invasion the Iraqis would pour into the streets bearing flowers and sweets, is a case in point (Dabashi 12).

In a historical footnote in Caramelo, Empress Carlota, "known to be a Western puppet" (96), was toppled by the disgruntled Mexicans and betrayed by Napoleon III and other Western allies, whose foreign intervention failed. "Abandoned and delirious, Carlota suffered a mental collapse and began to suspect everyone of trying to poison her" (Caramelo 96). Santa Anna too "as we recall, gave away half of Mexico to the United States" (Caramelo 96). Similarly, at the outset of Crescent, two CIA agents are looking for terrorists among the Middle Eastern students:

there were two grown men in business suits sitting at the counter every day writing things in pads. All they did was glance at the Middle Eastern students and take notes... One day after a month of sitting at the counter, the two men took the cook aside and asked if he knew of any 
terrorist schemes developing in the Arab-American community (Crescent 21).

The former owner of the restaurant, called Falafel Faraoh then, was terrified and sold the restaurant to his friend, Um-Nadia. This fear is ironically described as a terrible disillusion dawning upon him with the evaporation of all his hopes for fulfillment under the American Dream banner: "He'd never heard of such a thing in his life. He and his wife liked to watch Columbo at night: that was all he knew about intrigues or crime. He thought he was living in America" (Crescent 21). Um-Nadia, however, acted in a completely different way, funny and self-confident: "The two men in sunglasses promptly reappeared at the counter, but UmNadia, who said she'd seen worse in Beirut, chased them off the premises flapping her kitchen towel at them" (Crescent 21). Immediately afterwards in a very touching text, the reason behind her decisive action is clarified in Um-Nadia's compassion for the Arabs with their "allconsuming" loneliness that hovers like "a little shadow" (Crescent 21). Sirine too, though somehow ironically expressed, empathizes with the exaggerated emotional aspect of Arabs which turns tragic sometimes: "Arabs feel everything, larger than life, feelings walking in the sky" (Crescent 21).

Elsewhere in the novel, Arabs' paranoid fear of persecution is accentuated: "My uncle says it's the Arab disease. Where you keep thinking the CIA is following you around" (Crescent 130). Funnily, right afterwards, both Sirine and Han start suspecting Nathan as such. Towards the end of the novel, Han's narration of his past shows the role played by native informants, who brought disaster upon him and his family. Han's tragic bitterness stems out of his sense of guilt that the lives of his sister and brother, Leila and Aref, and of his friend Sami were wrecked because of "the so-called Ma'al, author of treasonous and deflamatory articles that attacked the Iraqi president", Ma'al being Han himself; "they had information that I'd had dealings with a certain American businessman, a known CIA informant" (Crescent 330), a reference to the husband of his beloved teacher of English, Janet. His relationship with his American teacher of English, whom he taught Arabic, was another reason why he had to flee to Cairo, then London, and finally, the US. "They said [Leila] was affiliated with American spies" (Crescent 330). Han has always been emotionally wrecked because of his sense of guilt. In a way, his story-telling uncovers both 
the dictatorial autocracy and surveillance in many Arab countries and the betrayal by some Western friends.

I wondered if Janet understood how dangerous it had been for me and my family to be associated with her. It began to seem as if my time at the private school had been a kind of brainwashing, with so much exposure to Western thoughts and values, a glorification of the West. Even after she'd spent all that money on me, I'd never learned Janet's last name or what she and her husband were really doing in my country. But she knew that Saddam Hussein was coming to power. She knew all sorts of things she shouldn't have known. And while I never really learned their motives, eventually I understood that in some way, deliberate or not, they were the ones who'd betrayed me (Crescent 331).

In his Constructing Postmodernism, Brian McHale traces paranoia in postmodernist, especially American, literature and links it to capitalism and conspiracy theory. In "postmodernist paranoid fictions", "conspiracy and counter-conspiracy, terrorist network and government intelligence agency, are clearly conceived of as displaced representations, at the content level, of the global capitalist network itself" (McHale 178). Whenever "the complexity of the social-economic system outstrips our capacity to represent it to ourselves, conspiracy theory", adds McHale, quoting Frederick Jameson's phrase, "arises to fill the gap as the 'poor person's cognitive mapping"” (McHale 179).

\section{Paratexts and Food as the Objective Correlative}

Food in Crescent works as the objective correlative, in other words, it plays the same role the rebozo plays in Caramelo. There is a parallelism between food and love, food and home, as well as food and identity: "the fine dicing of walnuts and the way to clarify butter were also meditations on hope and devotion" (Crescent 68), contemplates Sirine. "My mother told me that if I knew how to make baklava I would be irresistible to any woman" (Crescent 68), says Han. A beautifully crafted scene is structured of overlapping moments between pastry-making and happy or insecure moments. There is a crescendo, a rising action movement of parallel stretching of baklava dough sheets and harmonious rhythms between Sirine and Han. He 
aligns the next pastry perfectly. She paints the dough with clarified butter. . . it seems that she and Han know how to make baklava together. . . He transports the sheets and she sweeps the pastry brush, losing herself in the rocking movement. She takes in the powerful curve of his neck and shoulders (Crescent 67).

Discord hovers with reminiscences of Arab dictators and the poignancy of insecurity, on the part of Sirine and her fear of losing Han to Iraq, as well as Han's shattered sense of betrayal and exile. It starts with Han missing the kitchen, his mother and his home. "He accidentally tears a corner of a sheet of dough, it's starting to get dry. "I miss my mother's coffee/ I miss my mother's bread" (Crescent 68), he says probably quoting Mahmoud Darwish. This abrupt discrepancy is mirrored by the broken layers of baklava that cannot be patched, even when they both try to do so. Sirine tries, in vain, to patch the cracked layers of dough with butter (Crescent 69). She

pulls a pastry sheet off center, tearing it. She tries to pull it back into place, bites her lower lip. "Do you think you'll be back?"

His back stiffens. "I can't go back," he says. "To Iraq? No." . . " Not the way things are now, of course. It's very dangerous, it was terribly difficult for me to get out of the country in the first place." He tries to patch the last broken layer of dough together (Crescent 70).

Therefore, the parallel movement of an uprising action when they are happily making pastry together is immediately disrupted, turning into a discordant rhythm with the discrepancy of going home and notes of political exile. Significantly enough, like the broken dough layer, this insecurity and poignancy can never be patched.

Immediately after this baklava-making scene, Han invites Sirine to dinner at his home for the very first time. For her, he bakes "a sleeve of meat", "Just like mom used to make" (Crescent 76). The close relationship between them is obviously consolidated by food, itself reminiscent of home. Even though Han tasted Sirine's magnificent Arab recipes, he still thought of her as "all-American" (Crescent 76).

"It's Fairuz", Han Says. "I was going to play some American music for you but I guess I don't actually own any. I meant for tonight to be all-American for you." 
"But I'm not really all-American", Sirine says. (Crescent 76 , stress mine).

This stereotype of judging by appearances is commonly refuted in both Arab American and Chicana literature. There are books written on the maid, reproductive rabbit, or sexy Latina stereotype in the media advertisements and in Hollywood movies. Equally significant is the stereotype of Arab and Muslim women as either subservient, meek wives or terrorists. It is reminiscent of Gilbert and Gubar's critique of the depiction of women, or women writers, in the antithetical Jane Eyre as the angel or the "madwoman in the attic" as the monster or devil (Gilbert and Gubar 53).

Among the paratexts (or indices) included in the book are an autobiographical sketch, an important interview with Diana Abu-Jaber, and a few questions addressed to readers, further accentuating the metafictionality of the novel, as well as recipes for famous Arab dishes. In her autobiographical portrait, Abu-Jaber explains the somehow autobiographical similarity with Sirine. Both look American and both have learnt cooking as well as story-telling from their Arab fathers. It is as if the original Shahrazad is their father and the link to their original home is through narratives and food. The interview is an example of the paratexts included in the book; others include indices and questions. This could be the choice of Abu-Jaber herself or the editor. In both cases, there is the encroachment of reality upon the fictional text; the numerous interpretive and metafictional comments, together with the autobiographical similarities ruin the suspension of disbelief the reader might have enjoyed, since this follows immediately after the ending of the novel.

Therefore, the cultural dimensions of both Sandra Cisneros' Caramelo and Diana Abu-Jaber's Crescent can be perceived through a reading of their postmodernist technique as a reflection of the critical concepts of Jose David Saldivar's "borderlands" genre and cultural theory, Raul Homero Villa's "barrio-logos" and Gloria Anzaldua's "the Nueva Mestiza". If the terms are literal in the case of the Chicana Caramelo, they are metaphorically applied to Crescent, especially with Andalucia and The Arabian Nights looming in both works. Furthermore, amongst other techniques like metafiction, magic realism, stories-withinthe-story, multiple narrators, and interlinguality, paratexts, as thresholds of the text, culturally and technically accentuate the border concept shaping both novels. These cultural aspects, projected by postmodernist 
techniques, mirror the "borderland" genre and cultural theory. Both, as delineated by Saldivar, highlight cultural hybridity, the Chicana feminist, the postmodern, the postcolonial, and the comparative, intermingled with popular culture, bilinguality and dialogism. The borderland novelistic genre and cultural theory are situated physically or metaphorically at the liminal zone in both ethnic American novels. Furthermore, they are beautifully embodied by both Lala, in Caramelo, and Sirine, in Crescent, the new Shahrazad or the hybrid narrator, through whose exilic consciousness all tales are filtered and then offered in a borderland counternarrative. Indeed, both novels can be seen as examples of postmodernist Chicana and Arab American borderland fiction, where technique acts as culture. 


\section{Notes}

The following abbreviations will be used:

Saldivar, Border Matters: BM

Saldivar, Trans-Americanity: TA

Anzaldua, La Frontera: $\mathbf{L F}$

Anzaldua, La Conciencia de la Mestiza: CM

Anzaldua, Anzaldua Reader: AR

Hassan, Dismemberment of Orpheus

Hassan, Rumors of Change: $R C$

1. Mohja Kahf's "Men Kill Me" in Emails from Scheherazad (61).

2. Gloria Anzaldua's Borderlands/ La Frontera (1987): 1, quoted by Teresa McKenna (115).

3. Anzaldua (44), quoted by McKenna (115).

4. Anzaldua (73), quoted by McKenna (116).

5. Anzaldua (74), quoted by McKenna (116).

6. In my understanding of Sandra Cisneros' Caramelo, I am indebted to the lecture given by the critic Jose David Saldivar at Berkeley University, $4^{\text {th }}$ July, 2007.

7. "Experts" in this sense is a reference to Edward Said's Covering Islam: How the Media and the Experts Determine How We See the Rest of the World.

8. See Edward Said's Ph.D. thesis on Joseph Conrad (131, 151), The World, the Text and the Critic (49) and Culture and Imperialism $(97,367)$, where his notions of the ideological geography of the novel, filiation, affiliation, secular criticism, the gravity of history, and liminality, as related to postcolonial intellectuals in exile, are all expounded in depth. 


\section{Bibliography}

Abdelrazek, Amal Talaat. Contemporary Arab American Women Writers: Hyphenated Identities and Border Crossings. Cambria: New York, 2007.

Abu-Jaber, Diana. Crescent. Norton: New York, 2003.

. The Language of Baklava: A Memoir. 2005. Anchor Books: NY, 2006.

Allatson, Paul. Key Terms in Latino/a Cultural and Literary Studies. Blackwell: Malden, MA, 2007.

Anzaldua, Gloria. Borderlands/La Frontera: The New Mestiza. 1987. $25^{\text {th }}$ Anniversary. Fourth Edition. Aunt Lute Books: San Francisco, 2012.

. "La Conciencia de la Mestiza/ Towards a New Consciousness" from Borderlands/La Frontera: The New Mestiza in Latino Bloom: An Anthology of US Latino Literature. Eds. John S. Christie and Jose B. Gonzalez. Pearson, Longman, 2006: 413426.

. The Gloria Anzaldua Reader. Ed. AnaLouise Keating. Duke University Press: Durham \& London, 2009.

Barton, Edwin and Glenda Hudson. A Contemporary Guide to Literary Terms. Houghton Mifflin Company: Boston \& New York, 1997.

Baudrillard, Jean. America. 1986. Verso: London \& New York, 2010.

Brady, Mary Pat. Extinct Lands, Temporal Geographies: Chicana Literature and the Urgency of Space. Duke University Press: Durham \& London, 2002.

Bruce-Novoa, Juan. Retrospace: Collected Essays on Chicano Literature. Arte Publico Press, University of Houston: Texas, 1990.

Cisneros, Sandra. My Wicked Wicked Ways. 1987. Alfred A. Knopf: NY, 2009.

. Loose Woman. Vintage: NY, 1994.

. Woman Hollering Creek and Other Stories. Random House: NY, 1994.

. Caramelo. Vintage: New York, 2002.

Dabashi, Hamid. Brown Skin, White Masks. Pluto \& Fernwood: New York, 2011.

Fadda-Conrey, Carol. Racially White but Culturally Coloured: Defining Contemporary Arab American Literature and Its Transnational 
Connections. Ph.D. Dissertation. Purdue University: West Lafayette, Indiana, 2006.

Fanon, Frantz. Black Skin, White Masks. C 1952. Trans. Charles Lam Markmann. Paladin: Granada Pub. Co: London, 1970.

Gana, Nouri. "In Search of Andalusia: Reconfiguring Arabness in Diana Abu-Jaber's Crescent" in Comparative Literature Studies. Pennsylvania State University: PA. Vol. 45, No. 2, 2008: 228246.

Genette, Gerard. Paratexts: Thresholds of Interpretation. Trans. Jane E. Lewin. C 1987. Cambridge UP: New York, 1997.

Gilbert, Sandra and Susan Gubar. The Madwoman in the Attic: The Woman Writer and the Nineteenth-Century Literary Imagination.

C 1979. Yale UP: New Haven \& London, 2000.

Hassan, Ihab. Dismemberment of Orpheus: Toward a Postmodern Literature. University of Wisconsin Press, 1971 . Paracriticisms: Seven Speculations of the Times. University of Illinois Press, 1975

. Rumors of Change: Essays of Five Decades. University of Alabama Press, 1995.

Hoesterey, Ingeborg. Pastiche. Bloomington: Indiana University Press, 2001. Hutcheon, Linda. A Poetics of Postmodernism: History, Theory, Fiction. Routledge: London, 1990.

Kahf, Mohja. Emails from Scheherazad. University Press of Florida: Gainesville, 2003.

Lyotard, Jean-Francois. The Postmodern Condition: A Report on Knowledge. Trans. Geoff Bennington and Brian Massumi. Foreword by Frederic Jameson. Minneapolis: the University of Minnesota Press, 1984.

McHale, Brian. Constructing Postmodernism. Routledge: London \& New York, 1992.

McKenna, Teresa. Migrant Song: Politics and Process in Contemporary Chicano Literature. University of Texas Press: Austin, 1997.

Nyman, Jopi. Home, Identity, and Mobility in Contemporary Diasporic Fiction. Rodopi: New York, 2009.

Rose, Margaret. Parody/Metafiction. London: Croom Helm, 1979.

Sabry, Somaya Reda. Racing Sheherazade: Arab-American Women's Translation of Scheherazade in Writing and Performance. Ph.D. Dissertation. University of Western Ontario: Canada, 2009. 
Said, Edward. The Letters and Short Stories of Joseph Conrad. Ph.D. Thesis. Harvard University: Massachusetts, 1964.

. Covering Islam: How the Media and the Experts Determine How We See the Rest of the World. 1981. Vintage: NY, 1997.

. The World, the Text and the Critic. 1983. London: Vintage, 1991.

. Culture and Imperialism. 1993. London: Vintage, 1994.

Saldivar, Jose David. Border Matters: Remapping American Cultural Studies. University of California Press: Berkeley, 1997.

. "Lecture on Sandra Cisneros' Caramelo". Berkeley University,

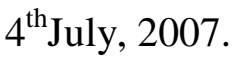

. Trans-Americanity: Subaltern Modernities, Global Coloniality and Cultures of Greater Mexico. Duke University Press: 2012.

Scholes, Robert. Fabulation and Metafiction. Chicago: University of Illinois Press: 1979.

Stavans, Ilan. A Critic's Journey. The University of Michigan Press: Ann Arbor, 2010.

Waller, Nicole. "Omar Sharif as Transnational Trickster: The Overlapping Geographies of Diana Abu-Jaber" in Virtually American? Denationalizing North American Studies. Heidelberg. Winter 2009: 135-146.

Villa, Raul Homero. Barrio-Logos: Space and Place in Urban Chicano Literature and Culture. University of Texas Press: Austin, 2000. 